\title{
An analytical technique of trace elements using LA-ICP-MS for tephra identification
}

\author{
S. KAGAMI $^{1 *}$, T. YOKOYAMA ${ }^{1}$ AND K. UMEDA ${ }^{2}$
}

${ }^{1}$ Japan Atomic Energy Agency (JAEA), Gifu, Japan

(*correspondance: kagami.saya@jaea.go.jp)

${ }^{2}$ Hirosaki University, Aomori, Japan

Tephrochronology is one of the geochronological techniques for Quaternary and generally used as well as radiocarbon dating. A catalogue of wide-spread tephras provides fundamental criteria for the establishment of a regional chronostratigraphy. Tephras have been identified by petrographic characteristics, types of volcanic glass shards in tephra, and major elements compositions of them [1]. Major element analyses of volcanic glass shards are usually carried out by EPMA. Recently, it has been reported that the some tephras which were quite similar to others in major element compositions were distinguishable by trace element compositions [e.g. 2]. Although trace element data of volcanic glass shards are important for tephra identification, the data are still lack in a catalogue of wide-spread tephras. To measure trace element abundances of the glass shards, laser ablation-inductively coupled plasma-mass spectrometry (LA-ICP-MS) is a powerful method because individual glass shards can be analyzed [e.g. 3,4].

In this study, we performed trace element analysis of tephras using LA-ICP-MS at Tono Geoscience Center, JAEA. We analyzed the concentration of 41 elements with the internal standard element of $\mathrm{Si}$ and two calibration standards of NIST SRM 612 and 614. Three tephra samples were prepared: Aso-4, Aira-Tn (AT), and Akogi (identified to ZnpOhta) tephras. While a fused glass bead of Aso-4 was prepared [5], the others were mounted on epoxy resin.

In Aso-4 and AT tephra samples, the concentrations of trace elements $(\mathrm{Rb}, \mathrm{Sr}, \mathrm{Y}, \mathrm{Zr}, \mathrm{Ba}, \mathrm{La}$, and $\mathrm{Ce})$, by which tephras are especially identified, were consistent with those in the previous studies [3,5] (RSD: $\sim 10 \%$ ). We obtained the pattern of trace element compositions of Akogi tephras, which was similar to that of Znp-Ohta tephras [6]. This analytical method will contribute to establish the detailed catalogue of tephras.

[1] Machida \& Arai (1992) Univ. of Tokyo press, 276. [2] Tamura et al. (2005) Jour. Geol. Soc. Japan, 111, 727. [3] Maruyama et al. (2019) The Quanternary Research 58, 333. [4] Furusawa (2017) Jour. Geol. Soc. Japan, 123, 765. [5] Kimura et al. (2018) Geochem. Jour. 52, 227. [6] Kimura et al. (2015) Geochem. Geophys. Geosyst. 16, 2147. 